\title{
COMPARISON OF BACKWARD AND FORWARD LINKAGES FOR INDUSTRIES IN THE BALTIC STATES AND FINLAND
}

\author{
Andrejs Jaunzems, Ilze Balode \\ Ventspils University of Applied Sciences, Latvia \\ jaunzems@venta.lv
}

\begin{abstract}
The goal of this paper is to conduct the comparative analysis of direct and total linkages, backward and forward linkages in the economies of the Baltic States and Finland in 2014. Measurement and comparison of the strengths of backward and forward linkages for the industries allow us to identify the "key" or "leading" industries of the national economy in the respective year, and to design certain clusters in order to classify the industries. We investigate the clusters of similar, in some sense, industries in the Baltic States and Finland, and offer an interpretation of the observed differences between these lists. The cluster analysis of the industry four linkages and share of industry output in the total output in five-dimensional space for Latvia, Lithuania, Estonia and Finland will be continued.
\end{abstract}

Key words: input-output model, interindustry coefficients, allocation coefficients, Leontief inverse, Ghosh inverse, direct and total linkages, backward and forward linkages.

\section{Introduction}

The general theoretical background of the current study in the wide sense is the Input-Output analysis offered by W. Leontief [1] and A. Ghosh [2]. The nowadays content of the Input-Output analysis is explored, for example, in the relevant book [3]: "Ronald E. Miller, Peter D. Blair. Inputoutput analysis. Foundations and extensions. Second Edition. - Cambridge University Press, 2013", and in a number of academic publications.

Let us shortly expound the theoretical input-output framework and the key concepts. Assume that the economy is categorized into $\mathrm{n}$ sectors. The input-output price model based on monetary data in current prices is constructed by utilizing the national account's balancing equations.

Definition [3], let $i, j=1,2, \ldots, n$;

1. the sum $a_{1 j}+a_{2 j}+\ldots+a_{n j}$, where $a_{i j}$ is the interindustry coefficient, is called the direct backward linkage of $\mathrm{j}$-th industry;

2. the sum $l_{1 j}+l_{2 j}+\ldots+l_{n j}$, where $l_{i j}$ is the element of the Leontief inverse matrix, is called the total direct backward linkage of $\mathrm{j}$-th industry;

3. the sum $b_{i 1}+b_{i 2}+\ldots+b_{i n}$, where $b_{i j}$ is the allocation coefficient, is called the direct forward linkage of i-th industry;

4. the sum $g_{1 j}+g_{2 j}+\ldots+g_{n j}$, where $g_{i j}$ is the element of the Ghosh inverse matrix, is called the total forward linkage of $j$-th industry.

The empirical material of the study is the "National Input-Output tables for the period 2000-2014" available thanks to World Input-Output Database (WIOD) with its unified structured statistical information in monetary terms (www.wiod.org). Timmer, M. P., Los, B., Stehrer, R. de Vries, G. J. comments [4]: "The new release includes data on 56 sectors and products mainly at the 2-digit ISIC revision 4 level (or groups thereof) together covering the overall economy. The WIOTs have an industry-by-industry format as many applications require such a square matrix reflecting the economic linkages across industries. They are built from national supply and use tables, which contain data on industries and products. The products are classified according to the CPA and cover 56 product categories following the primary outputs from our 56 sectors." An Illustrated User Guide to the World Input-Output Database is given by, R., de Vries, G. J. (2015).

As widely recognised, measurement of backward and forward, direct ad total linkages for the industries according to widespread opinion allows us to identify the "key" or "leading" industries of the national economy in the definite year, and to make the classification of industries. We have taken in account the scientific papers devoted to the economic structure studies with the help of interindustry linkages, for example, research of B. Šidlauskaite and A. Miškinis (2013) about the economic structure in the Baltic countries, and research of backward and forward linkages (comparative study of Poland and selected European countries) by Rumiana Gorska (2015), which allows us to state the contribution provided by our results. 
The discussion part of the paper is based on our calculations of four types of linkages and their interpretations according to the concepts explained below. Application of the cluster analysis leads to the identification of similar, in some sense, groups of industries in the Baltic States and Finland. Cluster analysis often used in conjunction with discriminant analysis is a descriptive analysis that may identify structures within the data. Our aim is identification of the most important reasons, which cause differences in the list of the "key" industries in the economies of Latvia (LTA), Lithuania (LTU), Estonia $(E S T)$ and Finland $(F I N)$. Our contribution is holistic analysis power of linkages in a strong connection with the relative weight of an industry as a total national output generator. In our opinion, the strong linkages alone do not signalize about "key status" of the industry, if its share in the total national output is small. Our attention is especially focused on the strengths of backward and forward linkages for the agriculture industries "Crop and animal production, hunting and related service activities" (A01), "Forestry and logging" (A02), "Fishing and aquaculture" (A03).

Note. All tables and all figures in the current paper are designed or obtained by the authors by using the NIOT data, mathematical models and tools of Microsoft Excel and SPSS 23.0.

\section{Materials and methods}

As mentioned in the introduction, the empirical material of the study is the "National InputOutput tables (NIOT) for the period of 2000-2014 “. Data for 56 sectors are classified according to the International Standard Industrial Classification revision 4. The NIOT are compiled in current prices, expressed in millions of US dollars; they represent the direct and dual systems of accounting balancing equations. The NIOT are considered as a reliable source of information. The WIOD is likely to provide further information, thus becoming a useful global empirical inventory for scientific and managerial needs.

Let us shortly describe the theoretical input-output framework and methods used. In our opinion, it is important to elaborate convincing interpretations of all kinds of linkages, which are clearly based on the proved mathematical connections. First, we should stress that the theoretical framework of this paper is directly connected with the theoretical background of the paper by Jaunzems published in the conference volume "Engineering for Rural Development, 2018", where the original version of inputoutput model adapted to the given structure of the NIOT is presented.

In order to explore the methods of linkage calculations, let us use a simplified model. We regard for honour utilizing the input-output example from the well-known and famous book "Wassily Leontief. Input-Output Economics. Second Edition. - Oxford University Press" [2]. In that way we offer some methodical innovation in order to explain the four types of linkages and their interpretations grounded only on the proved mathematical connections.

At first, we consider the input-output data for the two industries in natural units (Table 1).

The Leontief's' input-output example in natural units

Table 1

\begin{tabular}{|c|c|c|c|c|}
\hline & agriculture & production & final product & total output \\
\hline agriculture & 25 & 20 & 55 & 100 \\
\hline production & 14 & 6 & 30 & 50 \\
\hline primary factor & 80 & 180 & - & - \\
\hline
\end{tabular}

Let the price of one unit of an agriculture product be 2 USD, the price of one unit of production product -5 USD, the price of one unit of primary factor - 1 USD.

Next, we get direct and dual balances in the monetary terms (Table 2).

Table 2

The Leontief's' input-output example in monetary terms

\begin{tabular}{|l|c|c|c|c|}
\hline & agriculture & production & final product & total output \\
\hline agriculture & 50 & 40 & 110 & 200 \\
\hline production & 70 & 30 & 150 & 250 \\
\hline primary factor & 80 & 180 & - & - \\
\hline total output & 200 & 250 & - & - \\
\hline
\end{tabular}


Below the four steps (a_1), (a_2), (b_1), (b_2) for linkage calculations and interpretation are presented.

(a) By using data in Table 2 we obtain a matrix of interindustry coefficients denoted as A:

\begin{tabular}{|l|c|c|}
\hline interindustry matrix A & agriculture & production \\
\hline agriculture & 0.25 & 0.16 \\
\hline production & 0.35 & 0.12 \\
\hline
\end{tabular}

The balancing system:

$$
\begin{aligned}
& 200=0.25 \cdot 200+0.16 \cdot 250+110 \\
& 250=0.35 \cdot 200+0.12 \cdot 250+150
\end{aligned}
$$

ensures data for us to develop the direct input-output model:

$$
\begin{aligned}
& x_{1}=a_{11} \cdot x_{1}+a_{12} \cdot x_{2}+y_{1}, \\
& x_{2}=a_{21} \cdot x_{1}+a_{22} \cdot x_{2}+y_{2} .
\end{aligned}
$$

(a_1) Direct backward linkages are:

$$
\begin{aligned}
& a_{11}+a_{21}=0.25+0.35=0.60 \text { for agriculture; } \\
& a_{12}+a_{22}=0.16+0.12=0.28 \text { for production. }
\end{aligned}
$$

Interpretation. In the respective economy the producing total output for 1 USD in agriculture creates in economy demand for 0.60 USD. The producing total output for 1 USD in production creates demand for 0.28 USD.

Another interpretation follows from system (1). If total output in agriculture decreases for 1 USD, ceteris paribus, than the summary final product increases for $\left(a_{11}+a_{21}\right)-1$ dollars:

$$
\begin{aligned}
& y_{1}-1+a_{11}=\left(1-a_{11}\right) \cdot\left(x_{1}-1\right)-a_{12} \cdot x_{2} \\
& y_{2}+a_{21}=-a_{21} \cdot\left(x_{1}-1\right)+\left(1-a_{22}\right) \cdot x_{2} .
\end{aligned}
$$

Analogous interpretation can be given for direct backward linkage for production.

Equation

$$
y_{1}+y_{2}=\left(1-a_{11}-a_{21}\right) \cdot x_{1}+\left(1-a_{12}-a_{22}\right) \cdot x_{2}
$$

shows that sums

$$
\left(1-a_{11}-a_{21}\right),\left(1-a_{12}-a_{22}\right)
$$

are the final product multipliers.

For example, $1-\left(a_{11}+a_{21}\right)=1-0.60$ denotes the final product throughout all sectors of the economy that is associated with a 1 USD increase in total output of agriculture.

From system (1) the system (2) follows and the Leontief inverse matrix denoted as $S$ :

$$
\begin{aligned}
& x_{1}=s_{11} \cdot y_{1}+s_{12} \cdot y_{2}, 200=1.4570 \cdot 110+0.2649 \cdot 150 \\
& x_{2}=s_{21} \cdot y_{1}+s_{22} \cdot y_{2}, 250=0.5795 \cdot 110+1.2417 \cdot 150,
\end{aligned}
$$

\begin{tabular}{|c|c|c|}
\hline Leontief inverse S & agriculture & production \\
\hline agriculture & 1.4570 & 0.2649 \\
\hline production & 0.5795 & 1.2417 \\
\hline
\end{tabular}

(a_2) Total backward linkages are:

$$
\begin{aligned}
& s_{11}+s_{21}=1.4570+0.5795=2.0365 \text { for agriculture; } \\
& s_{12}+s_{22}=0.2649+1.2417=1.5066 \text { for production. }
\end{aligned}
$$

Interpretation. The final product for 1 USD in agriculture requires in the economy increasing of total output for 2.0365 USD. The final product for 1 USD in production requires increasing of total output for 1.5066 USD.

Equation 


$$
x_{1}+x_{2}=\left(s_{11}+s_{21}\right) \cdot y_{1}+\left(s_{12}+s_{22}\right) \cdot y_{2}
$$

shows that sums

$$
\left(s_{11}+s_{21}\right),\left(s_{12}+s_{22}\right)
$$

are total output multipliers. For example, $s_{11}+s_{21}=2.0365$ denotes the total new output throughout all sectors of the economy that is associated with a 1 USD increase in final demand of an agricultural product.

(b) Using data in Table 2 we obtain a matrix of allocation coefficients denoted as B:

\begin{tabular}{|l|c|c|}
\hline allocation coefficients B & agriculture & production \\
\hline agriculture & 0.25 & 0.20 \\
\hline production & 0.28 & 0.12 \\
\hline
\end{tabular}

The balancing system:

$$
\begin{aligned}
& 200=0.25 \cdot 200+0.28 \cdot 250+80 \\
& 250=0.20 \cdot 200+0.12 \cdot 50+180
\end{aligned}
$$

allows us construct the Ghosh system of equations:

$$
\begin{aligned}
& x_{1}=b_{11} \cdot x_{1}+b_{21} \cdot x_{2}+v_{1} \\
& x_{2}=b_{12} \cdot x_{1}+b_{22} \cdot x_{2}+v_{2},
\end{aligned}
$$

where $v_{1}, v_{2}$ - primary factors.

(b_1) Direct forward linkages are:

$$
\begin{aligned}
& b_{11}+b_{12}=0.25+0.20=0.45 \text { for agriculture } \\
& b_{21}+b_{22}=0.28+0.12=0.40 \text { for production }
\end{aligned}
$$

Interpretation. The producing total output for 1 USD in agriculture creates in economy demand for $0.60 \mathrm{USD}$.

Equation $b_{11}+b_{12}=0.45$ shows location of 1 USD agriculture product supply in economy as interindustry consumption:

$$
x_{1}+x_{2}=\left(b_{11}+b_{12}\right) \cdot x_{1}+\left(b_{21}+b_{22}\right) \cdot x_{2}+\left(v_{1}+v_{2}\right) .
$$

A similar interpretation may be given for direct forward linkage for production.

Equation

$$
v_{1}+v_{2}=\left(1-b_{11}-b_{12}\right) \cdot x_{1}+\left(1-b_{21}-b_{22}\right) \cdot x_{2}
$$

shows that sums

$$
\left(1-b_{11}-b_{12}\right),\left(1-b_{21}-b_{22}\right)
$$

are the value added multipliers.

For example, $1-\left(b_{11}+b_{12}\right)=1-0.45$ denotes the value added throughout all sectors of the economy that is associated with a 1 USD increase in total output of agriculture.

From system (3) the system (4) follows and the Ghosh inverse matrix denoted as G:

$$
\begin{aligned}
& x_{1}=g_{11} \cdot v_{1}+g_{21} \cdot v_{2}, 200=1.4570 \cdot 80+0.4636 \cdot 180, \\
& x_{2}=g_{12} \cdot v_{1}+g_{22} \cdot v_{2}, 250=0.3311 \cdot 80+1.2417 \cdot 180,
\end{aligned}
$$

\begin{tabular}{|l|c|c|}
\hline Ghosh inverse $\mathrm{G}$ & agriculture & production \\
\hline agriculture & 1.4570 & 0.3311 \\
\hline production & 0.4636 & 1.2417 \\
\hline
\end{tabular}

(b_2) Total forward linkages are:

$$
\begin{aligned}
& g_{11}+g_{12}=1.4570+0.3311=1.7881 \text { for agriculture; } \\
& g_{12}+g_{22}=0.4636+1.2417=1.7053 \text { for production } .
\end{aligned}
$$


Interpretation. Equation

$$
x_{1}+x_{2}=\left(g_{11}+g_{12}\right) \cdot v_{1}+\left(g_{21}+g_{22}\right) \cdot v_{2}
$$

shows that sums

$$
\left(g_{11}+g_{12}\right),\left(g_{21}+g_{22}\right)
$$

are total output multipliers. For example, $g_{11}+g_{12}=1.7881$ represents the effect of total output throughout all sectors of the economy that is associated with a 1 USD increase in primary input in agriculture.

\section{Results and discussion}

Results of calculations of linkages for the industries in 2014 are presented in Table 3 by using the following notations: EST - Estonia; FIN - Finland; LTA - Latvia; $L T U$ - Lithuania. DBL - direct backward linkages; $T B L$ - total backward linkages; $D F L$ - direct forward linkages; $T F L$ - total forward linkages; $P R$ - percent of the total output of industry as part of the national total output.

In order to ensure that the study is reader friendly, the list of codes and titles of the industries is given in spite of limited volume of the paper.

Industry linkages and percent of industry output in total output for

Table 3

\begin{tabular}{|c|c|c|c|c|c|c|c|c|c|c|c|c|c|c|c|c|c|c|c|c|}
\hline \multirow{2}{*}{ Code } & $E S T$ & $E S T$ & $E S T$ & $E S T$ & $E S T$ & $F I N$ & FIN & FIN & $F I N$ & FIN & $L T A$ & $L T A$ & LTA & $L T A$ & $L T A$ & $L T U$ & $L T U$ & $L T U$ & $L T U$ & $L T U$ \\
\hline & $D B L$ & $T B L$ & $D F L$ & $T F L$ & $P R$ & $D B L$ & $T B L$ & $D F L$ & $T F L$ & $P R$ & $D B L$ & $T B L$ & $D F L$ & $T F L$ & $P R$ & $D B L$ & $T B L$ & $D F L$ & $T F L$ & $P R$ \\
\hline$A 01$ & 0.37 & 1.58 & 0.50 & 1.71 & 2.25 & 0.50 & 1.91 & 0.65 & 2.23 & 1.26 & 0.39 & 1.69 & 0.39 & 1.55 & 2.79 & 0.33 & 1.45 & 0.36 & 1.40 & 4.05 \\
\hline$A 02$ & 0.40 & 1.64 & 0.68 & 1.95 & 1.25 & $\mid 0.24$ & 1.34 & 0.77 & 2.40 & 1.22 & $\mid 0.51$ & 1.98 & 0.70 & 2.25 & 1.93 & $\mid 0.36$ & 1.51 & 0.43 & 1.62 & 0.55 \\
\hline$A 03$ & 0.27 & 1.42 & 0.55 & 1.70 & 0.20 & 0.18 & 1.25 & 0.54 & 1.94 & 0.05 & 0.33 & 1.59 & 0.27 & 1.38 & 0.12 & 0.42 & 1.59 & 0.59 & 1.64 & 0.07 \\
\hline$B$ & 0.25 & 1.39 & 0.69 & 2.13 & 1.17 & 0.44 & 1.73 & 0.68 & 2.13 & 0.48 & 0.34 & 1.60 & 0.77 & 2.74 & 0.55 & 0.19 & 1.26 & 0.51 & 1.61 & 0.35 \\
\hline$C 10-C 12$ & 0.51 & 1.83 & 0.21 & 1.28 & 4.20 & 0.65 & 2.24 & 0.52 & 1.93 & 2.90 & 0.44 & 1.76 & 0.14 & 1.18 & 4.02 & 0.41 & 1.58 & 0.05 & 1.07 & 6.72 \\
\hline$C 13-C 15$ & 0.17 & 1.25 & 0.02 & 1.03 & 1.11 & $\mid 0.29$ & 1.47 & 0.15 & 1.24 & 0.31 & $\mid 0.29$ & 1.50 & 0.14 & 1.19 & 0.74 & 0.20 & 1.27 & 0.09 & 1.11 & 1.35 \\
\hline$C 16$ & 0.54 & 1.89 & 0.24 & 1.33 & 4.24 & 0.70 & 2.12 & 0.53 & 1.84 & 1.49 & 0.59 & 2.17 & 0.34 & 1.57 & 4.15 & 0.25 & 1.34 & 0.23 & 1.31 & 1.62 \\
\hline$C 17$ & 0.41 & 1.65 & 0.04 & 1.06 & 0.51 & 0.63 & 2.09 & 0.23 & 1.37 & 3.38 & 0.23 & 1.39 & 0.33 & 1.53 & 0.29 & 0.21 & 1.30 & 0.08 & 1.11 & 0.62 \\
\hline$C 18$ & 0.24 & 1.37 & 0.20 & 1.33 & 0.55 & $\mid 0.47$ & 1.85 & 0.70 & 2.32 & 0.33 & 0.34 & 1.57 & 0.63 & 2.05 & 0.47 & 0.11 & 1.15 & 0.78 & 2.14 & 0.38 \\
\hline$C 19$ & 0.33 & 1.49 & 0.28 & 1.48 & 0.70 & 0.28 & 1.46 & 0.29 & 1.51 & 2.49 & $\mid 0.60$ & 2.20 & 2.75 & 6.09 & 0.01 & 0.14 & 1.19 & 0.10 & 1.14 & 9.73 \\
\hline$C 20$ & 0.16 & 1.25 & 0.08 & 1.11 & 1.22 & 0.44 & 1.76 & 0.47 & 1.81 & 1.92 & 0.37 & 1.66 & 0.12 & 1.19 & 0.48 & 0.17 & 1.24 & 0.12 & 1.14 & 3.25 \\
\hline$C 21$ & 0.25 & 1.41 & 0.10 & 1.13 & 0.10 & 0.19 & 1.32 & 0.23 & 1.32 & 0.48 & 0.27 & 1.48 & 0.05 & 1.07 & 0.35 & 0.17 & 1.24 & 0.39 & 1.47 & 0.22 \\
\hline$C 22$ & 0.22 & 1.33 & 0.07 & 1.10 & 0.85 & 0.38 & 1.65 & 0.40 & 1.66 & 0.76 & 0.21 & 1.38 & 0.06 & 1.10 & 0.46 & 0.13 & 1.18 & 0.15 & 1.20 & 1.35 \\
\hline$C 23$ & 0.37 & 1.57 & 0.45 & 1.63 & 1.02 & 0.44 & 1.75 & 0.69 & 2.13 & 0.78 & $\mid 0.38$ & 1.69 & 0.39 & 1.69 & 1.12 & 0.30 & 1.42 & 0.22 & 1.30 & 0.88 \\
\hline$C 24$ & 0.10 & 1.16 & 0.02 & 1.03 & 0.17 & 0.51 & 1.89 & 0.41 & 1.69 & 2.34 & 0.33 & 1.59 & 0.02 & 1.03 & 0.75 & 0.23 & 1.32 & 0.08 & 1.11 & 0.17 \\
\hline$C 25$ & 0.20 & 1.29 & 0.24 & 1.33 & 2.57 & 0.44 & 1.75 & 0.65 & 2.05 & 1.71 & 0.19 & 1.34 & 0.43 & 1.73 & 1.27 & 0.24 & 1.33 & 0.29 & 1.41 & 1.05 \\
\hline$C 26$ & 0.08 & 1.12 & 0.01 & 1.01 & 4.42 & 0.34 & 1.53 & 0.27 & 1.44 & 2.82 & 0.18 & 1.33 & 0.01 & 1.01 & 0.40 & 0.13 & 1.17 & 0.29 & 1.39 & 0.35 \\
\hline C27 & 0.13 & 1.19 & 0.03 & 1.04 & 1.44 & 0.31 & 1.53 & 0.10 & 1.16 & 1.13 & $\mid 0.21$ & 1.38 & 0.01 & 1.01 & 0.42 & $\mid 0.19$ & 1.25 & 0.34 & 1.50 & 0.50 \\
\hline$C 28$ & 0.20 & 1.30 & 0.04 & 1.06 & 0.84 & 0.38 & 1.63 & 0.23 & 1.37 & 3.72 & 0.24 & 1.42 & 0.05 & 1.08 & 0.40 & 0.18 & 1.24 & 0.17 & 1.23 & 0.65 \\
\hline C29 & 0.14 & 1.21 & 0.01 & 1.02 & 0.76 & 0.30 & 1.51 & 0.07 & 1.11 & 0.38 & 0.26 & 1.44 & 0.14 & 1.26 & 0.27 & 0.34 & 1.45 & 0.53 & 1.84 & 0.34 \\
\hline C30 & 0.37 & 1.57 & 0.02 & 1.04 & 0.16 & $\mid 0.39$ & 1.66 & 0.16 & 1.28 & 0.42 & 0.31 & 1.51 & 0.13 & 1.23 & 0.20 & 0.21 & 1.29 & 0.45 & 1.82 & 0.27 \\
\hline C31_C32 & 0.32 & 1.52 & 0.07 & 1.09 & 1.50 & $\mid 0.41$ & 1.70 & 0.24 & 1.36 & 0.41 & 0.37 & 1.68 & 0.07 & 1.11 & 0.67 & $\mid 0.30$ & 1.41 & 0.14 & 1.17 & 2.65 \\
\hline C33 & 0.31 & 1.46 & 0.76 & 2.23 & 0.91 & 0.31 & 1.51 & 0.70 & 2.26 & 0.71 & 0.34 & 1.61 & 0.80 & 2.45 & 0.69 & 0.37 & 1.49 & 0.80 & 2.17 & 0.76 \\
\hline D35 & 0.38 & 1.56 & 0.54 & 1.80 & 3.58 & 0.31 & 1.51 & 0.77 & 2.23 & 2.22 & 0.56 & 2.10 & 0.71 & 2.41 & 5.76 & 0.31 & 1.44 & 0.53 & 1.80 & 3.11 \\
\hline E36 & 0.20 & 1.30 & 0.41 & 1.56 & 0.28 & 0.26 & 1.42 & 0.54 & 1.79 & 0.18 & 0.27 & 1.52 & 0.23 & 1.32 & 0.15 & 0.17 & 1.23 & 0.22 & 1.29 & 0.25 \\
\hline E37-E39 & 0.41 & 1.63 & 0.11 & 1.15 & 0.72 & $\mid 0.39$ & 1.66 & 0.78 & 2.33 & 0.72 & 0.30 & 1.53 & 0.26 & 1.35 & 0.58 & 0.27 & 1.37 & 0.21 & 1.26 & 0.69 \\
\hline
\end{tabular}

\section{Latvia, Lithuania, Estonia and Finland in 2014}


Table 3 (continued)

\begin{tabular}{|c|c|c|c|c|c|c|c|c|c|c|c|c|c|c|c|c|c|c|c|c|}
\hline & & & & & & & & & & IN & LTA & $\boldsymbol{T A}$ & $\boldsymbol{L T A}$ & $T A$ & $\boldsymbol{T A}$ & $\boldsymbol{T U}$ & $\boldsymbol{L T U}$ & $\boldsymbol{T U}$ & $\boldsymbol{T U}$ & \\
\hline & $D B L$ & $T B L$ & $D F L$ & $T F L$ & $P R$ & & & & $T F L$ & $P R$ & $D B L$ & & & TFL & & $D B L$ & $T B L$ & $D F L$ & $T F L$ & \\
\hline$F$ & & 57 & 18 & 25 & 7.56 & & & & 1.46 & 7.42 & & & & & & & & & 41 & 0 \\
\hline G4 & & 36 & 73 & 2.26 & & & & & & & & & & & & & & & & \\
\hline & & 56 & 35 & 1.49 & 4.88 & & & & 2.00 & 3.85 & & .83 & & 178 & .42 & 28 & .39 & 32 & 39 & 64 \\
\hline & & 54 & 31 & 1.46 & 3.73 & & 1.58 & & 1.26 & 3.03 & & 53 & 32 & 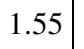 & .88 & 18 & .24 & & 18 & \\
\hline & & 59 & 69 & 2.09 & 4.55 & & & & 2.29 & 2.48 & & .86 & & 1.87 & J.JJ & 33 & 1.45 & & 46 & 0.7 \\
\hline & & 86 & .33 & 1.58 & $1.21 \|$ & 0.46 & 1.75 & 28 & 1.47 & 0.66 & 30 & .55 & 21 & 144 & .28 & 26 & .33 & 47 & 64 & 0.2 \\
\hline & & 85 & 37 & 1.62 & 0.32 & & & & 1.81 & 0.72 & & & & & & 48 & 66 & & 23 & \\
\hline & & 83 & 49 & 1.87 & 5.63 & 0.57 & 2.06 & & 2.92 & 1.74 & 59 & 2.24 & 0.76 & 2.11 & $0.7 J$ & 31 & 1.41 & 41 & .55 & . \\
\hline & & 55 & 72 & 2.24 & 0.27 & 0.40 & & & 2.50 & 0.40 & & & & 09 & 30 & 26 & .35 & 69 & 01 & 1 \\
\hline$I$ & & 69 & .16 & 1.24 & 2.05 & 50 & 1.89 & 29 & 1.43 & 1.87 & & 1.66 & 17 & 1.33 & 60 & 22 & 1.30 & 14 & 20 & 1.0 \\
\hline & & 59 & .55 & 1.86 & 0.33 & & & & 2.13 & 0.82 & & 1.81 & 20 & 1.32 & 25 & 34 & 1.46 & & 7 & \\
\hline D & & 73 & 53 & 2.00 & 0.43 & & 1.72 & & 1.78 & 0.46 & & .79 & & 1 & 29 & 44 & .66 & & 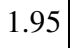 & 0.2 \\
\hline J01 & & 61 & 52 & 1.90 & 1.35 & 40 & 1.66 & & 2.00 & 1.07 & & 1.80 & & 1.87 & 1.05 & 21 & 1.28 & 36 & & 1.1 \\
\hline- & & 38 & 35 & 1.56 & 2.04 & & & & 1.67 & 2.58 & & 46 & & 1 & & 22 & 29 & & 27 & 0.9 \\
\hline & & 36 & 60 & 1.99 & 1.83 & 37 & 61 & 53 & 1.87 & 1.54 & & 1.60 & 58 & .11 & 69 & 33 & 1.45 & 67 & 99 & 1.2 \\
\hline & & & & 1.72 & 0.45 & & & & 1.39 & 0.72 & & & & & & 42 & 1.59 & & & 0.3 \\
\hline & & 76 & 74 & 2.43 & 0.39 & 44 & .71 & & 2.35 & 0.56 & & & 98 & 2.98 & & 44 & 1.63 & & & 0.1 \\
\hline & & & 41 & 1.64 & & & & & 1.42 & & & & & & & & & & & \\
\hline & & 45 & 71 & 2.18 & 1.53 & & & & 2.05 & 1.42 & & & & 2.53 & 28 & 27 & 1.36 & 73 & 08 & 1.3 \\
\hline$M / 1$ & & 50 & 78 & 2.18 & 0.77 & & & & 2.28 & 1.43 & & 1.73 & & 2.45 & & 30 & 1.41 & 60 & & 0.6 \\
\hline & & .26 & 02 & 1.03 & 0.66 & & & & 1.23 & 0.56 & & & & 1.0 & & & 1.20 & & & 0.1 \\
\hline & & 1.71 & 74 & 2.19 & 0.87 & 0.36 & 1.61 & 0.93 & 2.56 & 0.32 & 57 & 2.02 & 69 & 2.28 & 12 & 37 & 1.54 & 77 & 22 & 0.6 \\
\hline $1 / 4$ _M/5 & & & & 2.02 & & & & & 2.49 & 0.37 & & & & & & & & & & 0.2 \\
\hline$N$ & & 1.46 & 64 & 2.01 & 3.09 & 0.32 & 1.54 & 0.63 & 2.03 & 2.66 & 0.40 & 1.68 & 0.74 & 2.32 & 285 & 0.28 & 1.39 & .55 & 1.78 & 1.90 \\
\hline & & & & 1.06 & & & & & & & & & & & & & 1.31 & 0.01 & 1.02 & \\
\hline 100 & & 1.30 & 0.06 & 1.08 & 2.70 & 0.22 & | & 0.08 & 1.11 & 3.63 & 0.18 & 1.31 & 0.05 & 1.08 & 2.11 & 0.10 & 1.14 & 0.04 & 1.05 & 2.90 \\
\hline$Q$ & & 1.30 & 0.05 & 1.06 & & & & & 1.12 & 7.36 & 0.17 & 1.30 & & 1.04 & 2.06 & 0.25 & 1.34 & 0.05 & 1.06 & 2.61 \\
\hline-5 & & 1.58 & 20 & 1.28 & 2.23 & 0.39 & 1.64 & 0.15 & 1.24 & 2.77 & 0.35 & 1.58 & 0.15 & 1.25 & 2.38 & 0.39 & 1.56 & 0.26 & 1.35 & 1.9 \\
\hline
\end{tabular}

Code explanation:

- $\quad A 01$ - Crop and animal production, hunting and related service activities

- $A 02$ - Forestry and logging

- $A 03$ - Fishing and aquaculture

- $B$ - Mining and quarrying

- $C 10-C 12$ - Manufacture of food products, beverages and tobacco products

- C13-C15 - Manufacture of textiles, wearing apparel and leather products

- $C 16$ - Manufacture of wood and of products of wood and cork, except furniture; manufacture of articles of straw and plaiting materials

- $\quad C 17$ - Manufacture of paper and paper products

- $\mathrm{C} 18$ - Printing and reproduction of recorded media

- $C 19$ - Manufacture of coke and refined petroleum products

- $C 20$ - Manufacture of chemicals and chemical products

- $C 21$ - Manufacture of basic pharmaceutical products and pharmaceutical preparations

- $C 22$ - Manufacture of rubber and plastic products 
- $C 23$ - Manufacture of other non-metallic mineral products

- $\quad C 24$ - Manufacture of basic metals

- $C 25$ - Manufacture of fabricated metal products, except machinery and equipment

- $C 26$ - Manufacture of computer, electronic and optical products

- $\quad C 27$ - Manufacture of electrical equipment

- $C 28$ - Manufacture of machinery and equipment n.e.c.

- $C 29$ - Manufacture of motor vehicles, trailers and semi-trailers

- $C 30$ - Manufacture of other transport equipment

- C31_C32 - Manufacture of furniture; other manufacturing

- $C 33$ - Repair and installation of machinery and equipment

- D35 - Electricity, gas, steam and air conditioning supply

- E36 - Water collection, treatment and supply

- E37-E39 Sewerage; waste collection, treatment and disposal activities; materials recovery; remediation activities and other waste management services

- $\mathrm{F}$ - Construction

- G45 - Wholesale and retail trade and repair of motor vehicles and motorcycles

- $G 46$ - Wholesale trade, except of motor vehicles and motorcycles

- $G 47$ - Retail trade, except of motor vehicles and motorcycles

- $H 49$ - Land transport and transport via pipelines

- $H 50$ - Water transport

- H51 - Air transport

- H52 - Warehousing and support activities for transportation

- $\quad H 53$ - Postal and courier activities

- I- Accommodation and food service activities

- $\quad J 58$ - Publishing activities

- J59_J60 - Motion picture, video and television programme production, sound recording and music publishing activities; programming and broadcasting activities

- $J 61$ - Telecommunications

- J62_J63 - Computer programming, consultancy and related activities; information service activities

- $\quad K 64$ - Financial service activities, except insurance and pension funding

- $K 65$ - Insurance, reinsurance and pension funding, except compulsory social security

- $K 66$ - Activities auxiliary to financial services and insurance activities

- $\quad$ 668 - Real estate activities

- M69_M70 - Legal and accounting activities; activities of head offices; management consultancy activities

- $\quad M 71$ - Architectural and engineering activities; technical testing and analysis

- $\quad M 72$ - Scientific research and development

- $\quad M 73$ - Advertising and market research

- M74_M75 - Other professional, scientific and technical activities; veterinary activities

- $\quad N$ - Administrative and support service activities

- $O 84$ - Public administration and defence; compulsory social security

- $P 85$ - Education

- $Q$ - Human health and social work activities

- $\quad R \_S$ - Other service activities

The indicators in Table 3 are calculated by the authors according to the definitions in the introduction by using the NIOT data, mathematical models and tools of Microsoft Excel and SPSS 23.0. As we see, Table 3 contains a huge volume of information. We offer some methodical innovation to obtain the interpretations of the four types of linkages grounded only on the proved mathematical connections. Particularly, the linkages of the agriculture industries A02, A02, A03 presented in Table 3 may be interpreted by using the method explained in the chapter "Materials and Methods". 
In this paper we confine with two aspects.

The first (A): comparison of the structures of the national economies in the sense of range of industry according to its share in total national output.

The second (B): identification of the structure within the national industries with help of the cluster analysis in conjunction with the discriminant analysis. We have identified homogenous groups in five-dimensional space $\mathbf{R}^{5}$ in terms of the Euclidean metric.

(A) The industries with contribution in the total national output of Latvia of more than $5 \%$ are (see Table 4):

Table 4

Six industries in Latvia and corresponding industries in Estonia, Lithuania and Finland, 2014

\begin{tabular}{|c|c|c|c|c|c|c|c|c|c|c|c|c|c|c|c|c|c|c|c|c|}
\hline \multirow[t]{2}{*}{ Code } & EST & EST & EST & EST & EST & FIN & FIN & FIN & FIN & FIN & LTA & $\mathbf{I}$ & LT & LA & LTA & LTU & LT & 1 & LTU & LTU \\
\hline & DBL & IBL & DFL & TFL & PR & $\mathrm{DBL}$ & $1 \mathrm{DL}$ & DFL & TFL & PR & DBL & TBL & DFL & TFL & PR & DBL & TBL & DFL & TFL & PR \\
\hline $\mathrm{F}$ & \begin{tabular}{|l|}
0.37 \\
\end{tabular} & 1.57 & 0.18 & 1.25 & 7.56 & 0.46 & 1.8 & 0.30 & 1.46 & 7.42 & .57 & 2.10 & 0.46 & 1.83 & 11.37 & 0.32 & 1.45 & 0.29 & 1.41 & \begin{tabular}{|l}
6.97 \\
\end{tabular} \\
\hline L68 & 0.21 & 1.31 & 0.41 & 1.64 & 5.91 & 0.26 & 1.43 & 0.27 & 1.42 & 8.35 & 0.26 & 1.47 & 0.34 & 1.58 & 7.65 & 0.15 & 1.20 & 0.32 & 1.45 & 4.54 \\
\hline H52 & .50 & 1.83 & 0.49 & 1.87 & 5.63 & 0.57 & 2.06 & 0.91 & 2.92 & 1.74 & 0.59 & 2.24 & 0.76 & 2.71 & 6.45 & 0.31 & 1.41 & 0.41 & 1.55 & 3.88 \\
\hline G46 & .36 & 1.56 & 0.35 & 1.49 & 4.88 & 0.38 & 1.64 & 0.60 & 2.00 & 3.85 & 0.46 & 1.83 & 0.46 & 1.78 & 6.42 & 0.28 & 1.39 & 0.32 & 1.39 & 6.48 \\
\hline D35 & 0.38 & 1.56 & 0.54 & 1.80 & 3.58 & 0.31 & 1.51 & 0.77 & 2.23 & 2.22 & 0.56 & 2.10 & 0.71 & 2.41 & 5.76 & 0.31 & 1.44 & 0.53 & 1.80 & 3.11 \\
\hline $\mathrm{H} 49$ & 0.38 & 1.59 & 0.69 & 2.09 & 4.55 & 0.39 & 1.62 & 0.75 & 2.29 & 2.48 & 0.44 & 1.86 & 0.42 & 1.87 & 5.35 & 0.33 & 1.45 & 0.33 & 1.46 & 6.98 \\
\hline
\end{tabular}

Code explanation:

- $\mathrm{F}$ - Construction

- L68 - Real estate activities

- H52 - Warehousing and support activities for transportation

- G46 - Wholesale trade, except of motor vehicles and motorcycles

- D35 - Electricity, gas, steam and air conditioning supply

- H49 - Land transport and transport via pipelines.

The aggregate share of the biggest six industries amounts to $43.00 \%$ of the total national output in Latvia. The share of the same industries in the total national output is $32.11 \%$ in EST, $26.06 \%$ in FIN, $31.96 \%$ in $L T U$.

Table 4 presents the indicators, which are pithy interpreted. "Construction (F)", "Real estate activities (L68)" and "Wholesale trade, except of motor vehicles and motorcycles (G46)" are important industries in the Baltic States and Finland. It is easy to understand that in Finland the industry "Land transport and transport via pipelines (H49)" plays a smaller role than in Latvia and Lithuania. The geopolitical advantages of the Baltic States also explain the difference in the share of the industry "Warehousing and support activities for transportation (H52)" between the Baltic States $(5.63 \%, 6.45 \%, 3.88 \%$, respectively) and Finland (1.74\%).

(B) The results of the cluster analysis provided by SPSS 23.0 (K-Means Cluster Analysis, Discriminant Analysis). The industries of Baltic States and Finland were divided in the six clusters. The final cluster centres are presented in the tables 5-8.

Latvia: 6 clusters

- Cluster 1 (5 industries): $\{$ D35; G46; H49; H52; L68\}.

- Cluster 2 (1 industry): $\{\mathrm{F}\}$.

- Cluster 3 (15 industries): \{A02; B; C18; C23; C25; C33; G45; J61; J62_J63; K66; M69_M70; M71; M73; M74_M75\}.

- Cluster 4 (1 industry): $\{$ C19\}.

- Cluster 5 (10 industries): \{A01; C10-C12; C16; G47; H53; K64; N; O84; P85; Q; R_S_U\}.

- Cluster 6 (22 industries): \{A03; C13-C15;C17; C20; C21; C22; C24; C26; C27; C28; C29; C30; C31_C32; E36; E37-E39; H50; H51; I; J58; J59_J60; K65; M72\}. 
Final Cluster Centres, Latvia, 2014

Table 5

\begin{tabular}{|c|c|c|c|c|c|c|}
\hline \multirow{2}{*}{ Code } & \multicolumn{6}{|c|}{ Cluster } \\
\cline { 2 - 7 } & 1 & 2 & 3 & 4 & 5 & 6 \\
\hline DBL & 0.4633 & 0.5657 & 0.3668 & 0.5993 & 0.3450 & 0.3202 \\
\hline TBL & 10.9007 & 20.0953 & 10.6414 & 20.2022 & 10.6064 & 10.5622 \\
\hline DFL & 0.5383 & 0.4585 & 0.6627 & 20.7525 & 0.2787 & 0.1550 \\
\hline TFL & 20.0692 & 10.8332 & 20.2253 & 60.0947 & 10.4742 & 10.2621 \\
\hline PR & 60.3260 & 110.3700 & 0.9613 & 0.0100 & 30.2280 & 0.4695 \\
\hline
\end{tabular}

Latvia. $100.0 \%$ of original grouped cases correctly classified.

Lithuania: 6 clusters

- Cluster 1 (5 industries): $\{\mathrm{A} 01 ; \mathrm{G} 47 ; \mathrm{H} 52 ; \mathrm{L} 68 ; \mathrm{O} 84\}$.

- Cluster 2 (13 industries): \{C13-C15; C16; C22; C23; C25; G45; I; J61; J62_J63; K64; M69_M70; N; R_S_T_U\}.

- Cluster 3 (26 industries): $\{\mathrm{A} 02$; A03; B; C17; C18; C21; C24; C26; C27; C28; C29; C30; C33; E36; E37-E39; H50; H51; H53; J58; J59_J60; K65; K66; M71; M72; M73; M74_M75\}.

- Cluster 4 (1 industry): $\{\mathrm{C} 19\}$.

- Cluster 5 (4 industries): $\{\mathrm{C} 10-\mathrm{C} 12 ; \mathrm{F} ; \mathrm{G} 46 ; \mathrm{H} 49\}$.

- Cluster 6 (5 industries): $\{\mathrm{C} 20$; C31_C32; D35; P85; Q $\}$.

Final Cluster Centres, Lithuania, 2014

\begin{tabular}{|c|c|c|c|c|c|c|}
\hline \multirow{2}{*}{ Code } & \multicolumn{6}{|c|}{ Cluster } \\
\cline { 2 - 7 } & 1 & 2 & 3 & 4 & 5 & 6 \\
\hline DBL & 0.2368 & 0.2477 & 0.2776 & 0.1390 & 0.3334 & 0.2275 \\
\hline TBL & 10.3227 & 10.3399 & 10.3813 & 10.1905 & 10.4669 & 10.3148 \\
\hline DFL & 0.2476 & 0.3433 & 0.4030 & 0.0962 & 0.2485 & 0.1735 \\
\hline TFL & 10.3207 & 10.4892 & 10.5779 & 10.1374 & 10.3332 & 10.2454 \\
\hline PR & 40.3640 & 10.3362 & 0.3619 & 90.7300 & 60.7875 & 20.9040 \\
\hline
\end{tabular}

Lithuania. $100.0 \%$ of original grouped cases correctly classified.

Estonia: 6 clusters

- Cluster 1 (1 industry): $\{\mathrm{F}\}$.

- Cluster 2 (6 industries): $\{\mathrm{C} 10-\mathrm{C} 12 ; \mathrm{C} 16 ; \mathrm{C} 26 ; \mathrm{D} 35 ; \mathrm{G} 47 ; \mathrm{O} 84\}$.

- Cluster 3 (16 industries): $\{$ A03; C13-C15; C17; C18; C19; C20; C21; C22; C24; C28; C29; C30; E36; E37-E39; H51; M72\}.

- Cluster 4 (16 industries): \{A02; B; C23; C33; G45; H50; H53; J58; J59_J60; J61; K65; K66; M69_M70; M71; M73; M74_M75\}.

- Cluster 5 (4 industries): \{G46; H49; H52; L68\}.

- Cluster 6 (11 industries): \{A01; C25; C27; C31_C32; I; J62_J63; K64; N; P85; Q; R_S_T_U\}.

Table 7

Final Cluster Centres, Estonia, 2014

\begin{tabular}{|c|c|c|c|c|c|c|}
\hline \multirow{2}{*}{ Code } & \multicolumn{6}{|c|}{ Cluster } \\
\cline { 2 - 7 } & 1 & 2 & 3 & 4 & 5 & 6 \\
\hline DBL & 0.3738 & 0.3545 & 0.2606 & 0.3847 & 0.3601 & 0.2769 \\
\hline TBL & 10.5745 & 10.5518 & 10.4034 & 10.5956 & 10.5743 & 10.4234 \\
\hline DFL & 0.1768 & 0.2240 & 0.1475 & 0.6224 & 0.4855 & 0.2636 \\
\hline TFL & 10.2500 & 10.3238 & 10.2152 & 20.0318 & 10.7727 & 10.4009 \\
\hline PR & 70.56 & 40.08 & 0.57 & 0.86 & 50.24 & 20.19 \\
\hline
\end{tabular}

Estonia. $94.4 \%$ of original grouped cases correctly classified. 
Finland: 6 clusters

- Cluster 1 (3 industries): $\{\mathrm{F} ; \mathrm{L} 68 ; \mathrm{Q}\}$.

- Cluster 2 (13 industries): \{A01; A02; C16; C20; C25; D35; G45; H49; H52; I; K64; M69_M70; M71\}.

- Cluster 3 (12 industries): \{A03; B; C18; C23; C33; E37-E39; H53; J58; J61; K66; M73; M74_M75\}.

- Cluster 4 (1 industry): $\{084\}$.

- Cluster 5 (12 industries): \{C10-C12; C17; C19; C24; C26; C28; G46; G47; J62_J63; N; P85; R_S_T_U\}.

- Cluster 6 (13 industries): \{C13-C15; C21; C22; C27; C29; C30; C31_C32; E36; H50; H51; J59_J60; K65; M72\}.

Table 8

Final Cluster Centres, Finland, 2014

\begin{tabular}{|c|c|c|c|c|c|c|}
\hline \multirow{2}{*}{ Code } & \multicolumn{6}{|c|}{ Cluster } \\
\cline { 2 - 7 } & 1 & 2 & 3 & 4 & 5 & 6 \\
\hline DBL & 0.3352 & 0.4196 & 0.3946 & 0.3305 & 0.4009 & 0.3487 \\
\hline TBL & 10.5597 & 10.7091 & 10.6609 & 10.5350 & 10.6786 & 10.5825 \\
\hline DFL & 0.2209 & 0.6295 & 0.7307 & 0.1970 & 0.3305 & 0.2699 \\
\hline TFL & 10.3321 & 20.1161 & 20.2624 & 10.3281 & 10.5518 & 10.4323 \\
\hline PR & 70.7100 & 10.6631 & 0.5508 & 50.2200 & 30.0192 & 0.5531 \\
\hline
\end{tabular}

Finland. $100.0 \%$ of original grouped cases correctly classified.

As we see, the cluster analysis shows some similarity between the industry clusters in the Baltic States and Finland, but also differences at the same time. The cluster analysis of the industry linkages and percent of industry output in total output for Latvia, Lithuania, Estonia and Finland in 2014 explored in Table 3 has to be continued.

\section{Conclusions}

1. The comparative interindustry analysis, which is conducted by using the Input-Output model and National Input-Output tables with the unified structured statistical information as empirical material, is a powerful applied research method in economics. The calculated inter-industry linkages in the economies of the Baltic States and Finland in 2014 are based on "National InputOutput tables for the period 2000-2014" ensuring significant data for the economic structure studies under the theoretical input-output framework. A more holistic approach is to analyse the power of inter-industry linkages of the respective industry in strong connection with the relative weight of that industry as a total national output generator.

2. The successfully calculated six clusters of similar, in some sense, industries in the Baltic States and Finland by using SPSS 23.0 (K-Means Cluster Analysis, Discriminant Analysis) and the characteristics of each cluster through final cluster centres are the basis for classification of the industries. For example, in 2014 the leading "key" industry in the Baltic States (except Lithuania) and Finland was the industry "F - Construction". However, even in Lithuania the F industry with its linkages $D B L=0.33 ; T B L=1.47 ; D F L=0.25 ; T F L=1.33$ and very important weight in the national output $(P R=6.79 \%)$ keeps a strong position in the economy.

3. Evidently, the NIOT data on 56 sectors are a practically inexhaustible source of pithy information for an economic analysis. We are sorry to confine our report within the amount limits set for the paper. The studies will be continued.

\section{References}

[1] Leontief W. Input-Output Economics. Second Edition. - Oxford University Press. 1986, $436 \mathrm{pp}$.

[2] Ghosh A. Input-Output Approach to an Allocation System. - Economica, Vol. 25, No. 1, 1958, pp. 58-64. 
[3] Miller R.E. Input-output analysis. Foundations and extensions. Second Edition. - Cambridge University Press, 2013, 750 pp.

[4] Timmer M. P., Los B., Stehrer R. de Vries G. J. An Anatomy of the Global Trade Slowdown based on the WIOD 2016 Release. GGDC research memorandum, number 162. University of Groningen, 2016, 65 p.

[5] Timmer M. P., Dietzenbacher E., Los B., Stehrer R., de Vries G. J. An Illustrated User Guide to the World Input-Output Database: the Case of Global Automotive Production. - Review of International Economics, vol. 23, 2015, pp. 575-605.

[6] Šidlauskaitė B., Miškinis A. The Development of Economic Structure and Inter-Industry Linkages in the Baltic Countries. - Ekonomika, vol. 92(2), 2013, pp. 32-48.

[7] Gorska R. Backward and forward linkages based on an input-output analysis - comparative study of Poland and selected European countries. Applied Econometric Papers. Warsaw School of Economics (SGH), 2015, pp. 30-50. 